\title{
RANCANG BANGUN APLIKASI MEDIA PROMOSI HIDUP SEHAT BERBASIS ANDROID (STUDI KASUS DI DINAS KESEHATAN KABUPATEN SUMBAWA)
}

\author{
Shinta Esabella ${ }^{1}$, Fahri Hamdani ${ }^{2}$, Fahmi Yuliono ${ }^{13}$ \\ ${ }^{1)}$ Dosen Informatika Universitas Teknologi Sumbawa \\ ${ }^{2)}$ Dosen Informatika Universitas Teknologi Sumbawa \\ ${ }^{3)}$ Mahasiswa Informatika Universitas Teknologi Sumbawa \\ ${ }^{1}$ shintaesabella@uts.ac.id, ${ }^{2}$ fahri.hamdani@uts.ac.id, ${ }^{3}$ fahmyuliono@ gmail.com
}

\begin{abstract}
Abstrak
Penelitian ini bertujuan untuk merancang dan membangun Aplikasi Media Promosi Hidup Sehat Berbasis Android agar dapat dimanfaatkan oleh Dinas Kesehetan (DIKES). Adapun metode penelitian yang digunakan yaitu metode kualitatif yang bersifat deskriptif analitik dan metode pengumpulan data yang digunakan dalam penelitian ini yaitu metode wawancara, observasi, dan studi pustaka serta menggunakan metode spiral sebagai metode pengembangan perangkat lunak. Aplikasi Media Promosi Hidup Sehat Berbasis Android dibangun menggunakan Bahasa pemrograman Java dan basis data MySQL sebagai Database Management System (DBMS). Dalam Aplikasi Media Promosi Hidup Sehat Berbasis Android nantinya masyarakat sekitar khususnya di wilayah Kabupaten Sumbawa dapat memudahkan dalam melihat informasi kesehatan dimanapun dan kapanpun dalam bentuk berupa media digital.
\end{abstract}

Kata kunci: Android, Media Promosi, DIKES, Spiral.

\begin{abstract}
This research aims to design and build an Android-based healthy life promotion Media application in order to be utilized by the Health Department (DIKES). The research method used is a qualitative method of descriptive analytic and the method of data collection used in this research is the method of interviews, observations, and literature studies as well as using the method of spiral as Software development methods. The Android based healthy Live promotion Media app is built using the Java programming language and MySQL database as the Database Management System (DBMS). In the application of Healthy life promotion Media based on Android will be around especially in Sumbawa district can facilitate the viewing of health information wherever and whenever in the form of digital Media.
\end{abstract}

Keyword: Android, Media Promotion, DIKES, Spiral.

\section{PENDAHULUAN}

\section{Latar Belakang}

Seiring saat ini zaman semakin modern sangat penting memiliki pola hidup sehat yang dimana pola hidup lebih fokus pada kesehatan, baik itu perilaku, makanan, dan olahraga. Hingga saat ini pola hidup sehat selalu terlupakan dengan seiring banyaknya aktivitas yang dilakukan oleh manusia. Hal tersebut nantinya dapat berdampak secara langsung terhadap tubuh karena kurangnya menjaga pola hidup sehat secara baik dan benar.

Masyarakat Indonesia saat ini masih jauh dari pola hidup sehat. Bahkan, berdasarkan survei yang diinisiasi perusahaan asuransi AIA Group di 15 negara Asia Pasifik, Indonesia menempati peringkat terendah dalam penerapan pola hidup sehat. Dalam survei itu, Indonesia meraih skor 55 dari batas skor 100 dalam AIA Healthy Living Index 2013. Kendatipun Indonesia tercatat sebagai luas wilayah yang sangat besar di Asia Tenggara dengan jumlah penduduk yang banyak tersebar di berbagai Provinsi, Kota bahkan Kabupaten tetapi tetap saja sedikit diantara masyarakat Indonesia yang sudah sadar akan pentingnya menjaga pola hidup sehat yang benar. Hal ini disebabkan masyarakat di Indonesia masih banyak yang belum tahu bagaimana melakukan pola hidup yang baik dan benar. (Sumber: www.beritasatu.com/asuransi/1564).

Kabupaten Sumbawa adalah suatu Kabupaten yang berada di Provinsi Nusa Tenggara Barat. Berdasarkan estimasi penduduk yang diolah oleh Dinas Kesehatan Kabupaten Sumbawa didapatkan data bahwa jumlah penduduk Kabupaten Sumbawa tahun 2014 sebanyak 439.914 jiwa dengan rata-rata jumlah laki-laki 223.904 jiwa dan perempuan 216.010 jiwa. Dalam rangka mewujudkan visi pembangunan kesehatan Kabupaten Sumbawa yang tertuang dalam renstra Dinas Kesehatan Kabupaten Sumbawa Tahun 2016-2021 yaitu "Terwujudnya Pelayanan Kesehatan yang Berkualitas dalam Meningkatkan Derajat Kesehatan Masyarakat Sumbawa" visi ini dimaksudkan bahwa jajaran kesehatan mampu memberikan pelayanan kesehatan yang berkualitas kepada masyarakat agar terwujud derajat kesehatan masyarakat di Kabupaten Sumbawa yang semakin tinggi, sehingga mampu bersaing dengan daerah-daerah lain yang ada di 
Provinsi Nusa Tenggara Barat dan bahkan daerahdaerah di Pulau Jawa. Berkaitan dengan visi tersebut, Dinas Kesehatan berupaya menata kualitas dari sistem informasi kesehatan Kabupaten yang selanjutnya akan sangat menentukan sistem informasi kesehatan nasional. Oleh karena itu, penataan kembali dan pengembangan sistem informasi kesehatan Kabupaten merupakan sesuatu yang sangat penting. (Sumber: Profil Kesehatan Kabupaten Sumbawa Tahun 2016).

Dinas Kesehatan Kabupaten Sumbawa memiliki Bidang Promosi dan Pemberdayaan Masyarakat untuk melayani kesehatan masyarakat Kabupaten Sumbawa terdiri dari pelayanan kesehatan dasar, akses dan mutu pelayanan kesehatan, peningkatan perilaku hidup bersih dan sehat, pembinaan kesehatan lingkungan dan sanitasi dasar, pelayanan kesehatan di rumah sakit, dan pelayanan kefarmasian.

Pada Bidang Promosi dan Pemberdayaan Masyarakat selama ini dalam mempromosikan media tentang hidup sehat penyampaiannya dilakukan melalui sosialisasi, pamflet, brosur, leflet, buku saku, spanduk dan baliho. Namun terkadang melalui sosialisasi tersebut masyarakat ada saja yang tidak dapat hadir karena kurangnya minat dan kesibukan. Kemudian dengan adanya pamflet, brosur, leflet, buku saku, spanduk, dan baliho, masyarakat terkadang hanya mengambil dan melihatnya saja tanpa langsung dibaca bahkan sampai disimpan hingga hilang begitu saja. Seperti yang disampaikan oleh Bapak A. Gani, S.Km. Selaku Kepala Seksi Promosi dan Pemberdayaan Masyarakat dalam proses wawancara yang peneliti lakukan, beliau menyampaikan:

"Saya sangat mendukung dengan dibuatkannya aplikasi media promosi hidup sehat, karena aplikasi tersebut juga sudah sangat diinginkan sejak lama oleh Dinas Kesehatan Kabupaten Sumbawa."

Terkait dengan permasalahan diatas, dibutuhkan teknologi untuk memudahkan masyarakat mengatur pola hidup sehat yang memanfaatkan kecanggihan smartphone. Sistem operasi Android saat ini banyak dipakai oleh masyarakat di Indonesia karena sistem operasi Android memiliki banyak kelebihan. Salah satu kelebihan dari sistem operasi Android yaitu bersifat open source maka pengembangan aplikasi akan lebih mudah. Dengan adanya smartphone masyarakat di Kabupaten Sumbawa nantinya akan lebih mudah mengetahui betapa pentingnya menjaga pola hidup sehat.

Berdasarkan uraian permasalahan tersebut, peneliti berpandangan bahwa media promosi hidup sehat sangat penting untuk memberikan kemudahan kepada pengguna yang ingin mengikuti pola hidup sehat. Sehingga terhindar dari berbagai penyakit yang disebabkan oleh salahnya pola hidup yang dilakukan atau tidak sesuai dengan kondisi tubuh. Maka peneliti tertarik untuk melakukan penelitian tentang "Rancang Bangun Aplikasi Media Promosi Hidup Sehat Berbasis Android".

\section{Rumusan Masalah}

Dengan mengacu pada latar belakang masalah diatas maka disusun rumusan masalah yang akan dibahas dalam jurnal ini adalah "Bagaimana Merancang dan Membangun Aplikasi Media Promosi Hidup Sehat Berbasis Android?’.

\section{Batasan Masalah}

Adapun batasan masalah dalam penelitian ini sebagai berikut:

1. Perolehan data berasal dari proses pengumpulan data dengan teknik observasi, wawancara, dan dokumentasi di Dinas Kesehatan Kabupaten Sumbawa.

2. Tempat penelitian di Dinas Kesehatan Kabupaten Sumbawa.

3. Aplikasi yang dibangun digunakan untuk media promosi hidup sehat.

4. Aplikasi yang akan dibangun adalah dalam bentuk aplikasi Android Native.

5. Software yang digunakan dalam merancang dan membangun aplikasi media promosi hidup sehat berbasis android, yaitu:

a. Menggunakan Bahasa pemrograman JavaScript dan Java Android.

b. Menggunakan Sublime Text 3 sebagai text editor.

c. Menggunakan Android Studio sebagai IDE (Integrated Development Environment).

d. Menggunakan MySQL sebagai database.

e. Menggunakan XAMPP sebagai server.

\section{Tujuan Penelitian}

Adapun tujuan dalam penelitian ini yaitu merancang dan membangun aplikasi media promosi hidup sehat berbasis android yang dapat dimanfaatkan oleh masyarakat bertujuan untuk memudahkan masyarakat dalam mengelola hidup sehat dengan baik dan benar.

Manfaat Penelitian

Adapun manfaat dalam penelitian ditinjau secara teoritis dan praktis yaitu sebagai berikut:

a. Teoritis

Hasil Penelitian ini secara teoritis diharapkan dapat memberikan sumbangan pemikiran dalam memperkaya wawasan konsep media promosi hidup sehat terutama tentang mempromosikan informasi kesehatan untuk masyarakat di Kabupaten Sumbawa.

b. Manfaat Teoritis 
Memberikan informasi bagi masyarakat terkait segala hal yang bertujuan pada peningkatan kualitas kesehatan, baik itu kesehatan individu maupun masyarakat.

\section{Sistematika Penulisan}

Untuk memberi gambaran menegenai penelitian ini, maka disusunlah sistematika penulisan yang berisi tentang materi yang dibahas dari setiap sub bab.

\section{Landasan Teori}

\section{Tinjauan Pustaka}

Melihat dari pesatnya perkembangan teknologi, banyak terdapat beberapa penelitian yang berkaitan dengan yang sedang diteliti. Akan tetapi metode dan studi kasus dari sistem yang digunakan berbedabeda serta penggunaan teknologi yang beraneka ragam. Hal tersebut dapat disebabkan oleh kebutuhan dan teknologi yang digunakan. Beberapa penelitian sebelumnya yang dilakukan antara lain:

Penelitian pertama yang mempunyai keterkaitan dengan penelitian yang sedang diteliti adalah Penelitian dari mahasiswi yang bernama Rita Astari (2018) dengan judul "Rancang Bangun Aplikasi Pengelolaan Hidup Sehat berbasis Android'. Tujuan penelitian ini adalah memberikan kemudahan kepada masyarakat yang ingin mengikuti pola hidup yang sesuai dengan tinggi rendahnya kadar kolesterol, asam urat, dan gula darah. Sehingga terhindar dari berbagai keluhan yang disebabkan oleh salahnya pola hidup yang dilakukan atau tidak sesuai dengan kondisi tubuh. Metode yang digunakan dalam penelitian ini menggunakan pengembangan perangkat lunak waterfall, dan metode permodelan berorientasi objek yaitu menggunakan metode UML (Unified Modeling Language).

Hasil penelitian menunjukan aplikasi berjalan dengan semestinya karena aplikasi dapat memberikan informasi konsumsi kalori perhari kepada pengguna serta mengatur pola makan dan hidup sehat. Dan jika pengguna yang memiliki penyakit, makanan yang akan ditampilkan hanya makanan yang diperbolehkan untuk penyakit itu saja.

Demikian hasil observasi yang peneliti temukan, karena terdapat judul serta permasalahan yang mempunyai kesamaan dengan penelitian yang diteliti, walaupun demikian dalam penelitian yang peneliti lakukan terdapat beberapa perbedaan yaitu lokasi penelitian, data penelitian serta perancangan sistem yang berbeda dari penelitian sebelumnya.

\section{Dasar Teori}

Adapun dasar teori yang mendukung dalam pembuatan laporan ini sebagai berikut:

\section{Definisi Rancang Bangun Aplikasi}

Menurut Amin (2016), Perancangan terstruktur adalah suatu pendekatan yang bekerja dari sudut pandang yang lebih tinggi menuju tingkat lebih rendah yang lebih rinci, dimana keinginan pemakai disajikan dalam diagram alir data.

Menurut Sujadi (2015), Perancangan berorientasi objek adalah tahapan merancang kelaskelas yang teridentifikasi selama tahap analisis dan antarmuka pengguna (user interface) serta memungkinkan adanya penambahan beberapa objek dan kelas yang mendukung implementasi dari spesifikasi kebutuhan.

Berkaca dari kedua definisi di atas, maka dapat disimpulkan bahwa rancang bangun aplikasi yaitu kegiatan menterjemahkan hasil analisis suatu sistem ke dalam bentuk perangkat lunak untuk meningkatkan memudahkan dan meningkatkan kualitas suatu kegiatan atau pekerjaan.

\section{Definisi Media}

Menurut Sutirman (2013), Association of Education and Communication Technology (AECT) memberikan definisi media sebagai sistem transmisi (bahan dan peralatan) yang tersedia untuk menyampaikan pesan tertentu. Kamus Besar Ilmu Pengetahuan media merupakan perantara/penghubung yang terletak antara dua pihak, atau sarana komunikasi seperti koran, majalah, radio, televisi, film, poster, dan spanduk. Kata media berasal dari bahasa Latin yaitu medius yang artinya tengah, perantara atau pengantar. Kata media, merupakan bentuk jamak dari kata "medium", yang secara etimologi berarti perantara atau pengantar.

Menurut Sukarsih (2002), Media merupakan segala sesuatu yang dapat digunakan untuk mencapai tujuan pengajaran. Pengaturan media pembelajaran dan perabot kelas harus sedemikian rupa sehingga mendukung suasana belajar mengajar.

Dari beberapa penjelasan di atas, dapat disimpulkan bahwa media adalah alat untuk menyampaikan informasi kepada penerima dan segala sesuatu yang dapat digunakan untuk menyalurkan pesan dari pengirim ke penerima sehingga dapat merangsang pikiran, perasaan, perhatian agar terjadi komunikasi yang efektif dan efisien.

\section{Definisi Promosi}

Menurut Gitosudarmo (2014), mengemukakan bahwa promosi merupakan kegiatan yang ditujukan untuk mempengaruhi konsumen agar mereka dapat menjadi kenal akan produk yang ditawarkan oleh 
perusahaan kepada mereka yang kemudian mereka menjadi senang lalu membeli produk tersebut. Salah satu untuk membantu perusahaan dalam mengadakan komunikasi dengan konsumen adalah promosi dapat disampaikan informasi berupa pengetahuan mengenai produk yang ditawarkan.

Menurut Lupiyoadi (2006), Promosi merupakan salah satu variabel dalam bauran pemasaran yang sangat penting dilaksanakan oleh perusahaan dalam memasarkan produk jasa. Kegiatan promosi bukan saja berfungsi sebagai alat komunikasi antara perusahaan dengan konsumen, melainkan juga sebagai alat untuk mempengaruhi konsumen dalam kegiatan pembelian atau penggunaan jasa sesuai dengan keinganan dan kebutuhannya.

\section{Dinas Kesehatan Kabupaten Sumbawa}

Berdasarkan peraturan Bupati Sumbawa No.56 Tahun 2016 tentang rincian tugas, fungsi dan tata kerja Dinas Kesehatan Kabupaten Sumbawa bahwa Dinas kesehatan dipimpin oleh seorang Kepala Dinas. Unsur pembantu pimpinan terdiri dari sekretariat dan 4 (empat) bidang. Sekretariat membawahi 3 (tiga) Sub bag sedangkan 4 (empat) bidang yang ada masing masing membawahi 3 (tiga) seksi. Kepala Dinas juga dibantu oleh 25 Unit Pelaksana Teknis (UPT) Puskesmas dan 1 (satu) UPT Instalasi Farmasi Kabupaten.

\section{Definisi Metode Spiral}

Menurut Pressman (2005), terdapat sebuah model proses yang merupakan penggabungan antara model waterfall dan prototyping dimana perancangan dilakukan menggunakan model waterfall setelah itu membuat prototyping, yaitu Model Spiral. Model ini ditemukan sekitar tahun 1988 oleh Barry Boehm "A Spiral Model of Software Development and Enhancement". Merupakan salah satu bentuk evolusi yang digabungkan dengan aspek sistematis yang dikembangkan dengan model waterfall. Tahap desain umumnya digunakan pada model waterfall, sedangkan tahap prototyping adalah suatu model dimana perangkat lunak dibuat prototype (incomplete model), blue-print, atau contohnya dan ditunjukkan kepada pengguna untuk mendapatkan respon. Jika prototype sudah sesuai dengan keinginan pengguna, maka proses dilanjutkan dengan membuat produk sesungguhnya dengan menambah dan memperbaiki kekurangan dari prototype tadi.

Aplikasi yang akan dibangun oleh peneliti yaitu berskala besar dan bisa dikembangkan kembali ketika aplikasi tersebut sudah berhasil dibangun oleh peneliti. Peneliti dapat memakai metode spiral dikarenakan lebih cocok untuk pengembangan sistem dan perangkat lunak berskala besar.

\section{Metode Penelitian Kualitatif}

Menurut Suyito (2015) dasar penelitian kualitatif adalah konstruktivisme yang berasumsi bahwa kenyataan itu berdimensi jamak, interaktif dan suatu pertukaran pengalaman sosial yang diinterpretasikan oleh setiap individu.

Menurut Creswell (2009) mendefinisikannya sebagai suatu pendekatan atau penelusuran untuk mengeksplorasi dan memahami suatu gejala sentral. Untuk mengerti gejala sentral tersebut peneliti mewawancarai peserta penelitian atau partisipan dengan mengajukan pertanyaan yang umum dan agak luas.

Berdasarkan pernyataan dari para ahli peneliti dapat mengambil kesimpulan bahwa metode penelitian kualitatif adalah suatu pendekatan atau penelusuran untuk mengeksplorasi dan memahami suatu gejala sentral yang diinterpretasikan oleh setiap individu.

\section{Definisi Android}

Menurut Supardi (2017), Android merupakan sebuah sistem operasi perangkat mobile berbasis linux yang mencakup sistem operasi, middleware, dan aplikasi.

Menurut Safaat (2012), Android merupakan sistem operasi berbasis Linux bagi telepon selular seperti telpon pintar dan komputer tablet. Android juga menyediakan platform terbuka bagi para developer untuk menciptakan aplikasi mereka sendiri yang akan digunakan untuk berbagai macam piranti gerak. Awalnya, Google Inc. membeli Android Inc., pendatang baru yang membuat software untuk ponsel. Kemudian dalam pengembangan Android, dibentuklah Open Handset Alliance, konsorsium dari 34 perusahaan Hardware, Software dan telekomunikasi, termasuk Google, HTC, Intel, Motorola, Qualcomm, T-Mobile, dan Nvidia.

\section{Metodologi Penelitian}

1. Metode Penelitian

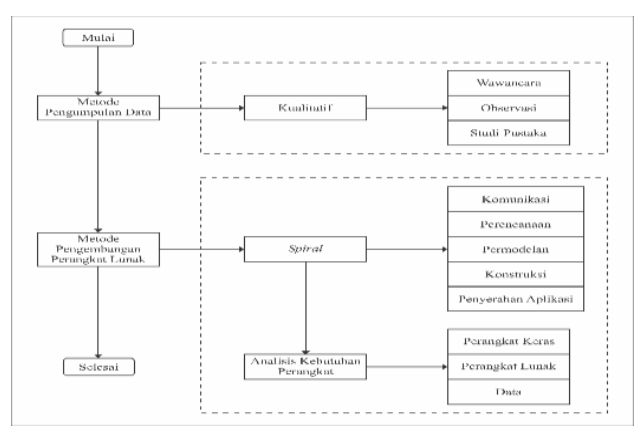




\section{Metode Pengembangan Perangkat Lunak}

Metode pengembangan perangkat lunak yang digunakan adalah metode spiral. Metode spiral merupakan perbaikan dari model waterfall dan prototype dengan menggabungkan keuntungan dari kedua model tersebut. Selain itu, metode spiral dirancang secara revolusioner dengan tahapan yang jelas dan terbuka bagi partisipasi pemesan untuk ikut serta dalam menentukan pemodelan sistem. Dalam metode tersebut, terdapat beberapa tahapan dalam rancang bangun sistem seperti terlihat pada gambar 3.2 dibawah ini:
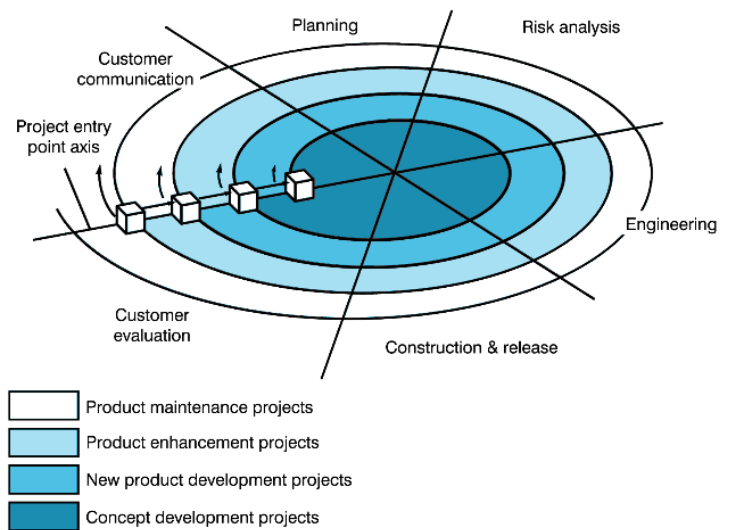

Gambar 3.2 Alur Penelitian

Berdasarkan gambar diatas, adapun berikut penjelasan mengenai tahapan-tahapan metode spiral, yaitu:

1. Komunikasi Pelanggan (Customer Comunication)

Dalam tahap ini penelitian dilakukan dengan cara berkomunikasi antar pengembang dan user secara efektif untuk identifikasi masalah dan penentuan kebutuhan kerja. Komunikasi yang dilakukan untuk mendapatkan dan mengumpulkan bahan dan data penelitian sesuai dengan apa yang dibutuhkan. dalam hal ini ada beberapa teknik yang dilakukan yaitu:

a. Wawancara

Wawancara merupakan percakapan antar dua pihak dengan maksud tertentu. Dalam penelitian ini, wawancara dilakukan bertujuan untuk memperoleh izin dalam melakukan penelitan mengenai bahan dan data yang dibutuhkan dalam penelitian rancang bangun aplikasi.

b. Observasi

Observasi dilakukan dengan melakukan pengamatan langsung pada Dinas Kesehatan Kabupaten Sumbawa untuk mengidentifikasi masalah dan analisis kebutuhan rancang bangun aplikasi yang akan dilakukan.

c. Dokumentasi

Dokumentasi digunakan untuk melengkapi kebutuhan dan kesempurnaan data penelitian yang dilakukan di Dinas Kesehatan Kabupaten Sumbawa. Data diambil berdasarkan sumber data tambahan yang terbagi atas sumber data arsip atau dokumentasi resmi lainnya yang berada di Dinas Kesehatan Kabupaten Sumbawa.

2. Perencanaan (Planning)

Dalam tahap ini penelitian dilakukan dengan mendefinisikan sumber daya, batas waktu, serta rencana dalam rancang bangun sistem yang akan dilakukan.

3. Analisis (Analysis)

Dalam tahap ini dilakukan dengan melakukan analisis data dari hasil wawancara dan observasi yang telah dilakukan untuk menentukan kebutuhan alat dan bahan dalam rancang bangun aplikasi.

4. Teknik (Engineering)

Dalam tahap ini penelitian dilakukan dengan cara membuat atau merancang bangun aplikasi sesuai dengan identifikasi masalah dan analisis yang telah dilakukan. Permodelan data akan dibuat dengan menggunakan Data Flow Diagram (DFD) untuk menjelaskan secara rinci dan detail mengenai rancang bangun sistem yang akan dilakukan.

\section{Konstuksi \& Rilis (Construction \& Release)}

Dalam tahap ini dilakukan dengan uji coba sistem yang telah dibangun untuk mengetahui apakah aplikasi sudah berjalan sesuai dengan apa yang diharapkan.

6. Evaluasi Pelanggan (Customer Evaluation)

Dalam tahap ini merupakan tahap evaluasi dari aplikasi yang telah dibangun dan di uji coba sebagai acuan untuk menentukan alur aplikasi yang berjalan sesuai dengan prosedur-prosedur dalam rancang bangun aplikasi yang telah dilakukan.

\section{Analisis Kebutuhan}

Dalam merancang dan membangun Aplikasi Media Promosi Hidup Sehat Berbasis Android mempunyai kebutuhan yang harus dipenuhi seperti kebutuhan perangkat keras (Hardware) dan kebutuhan perangkat lunak (Software). Berdasarkan penelitian yang dilakukan, adapun alat dan bahan penelitian yang digunakan yaitu:

1. Perangkat Keras (Hardware)

Untuk melakukan penelitian dalam merancang bangun aplikasi dibutuhkan dua perangkat keras (hardware) yaitu laptop dan smartphone dengan spesifikasi sebagai berikut:

\section{a. Laptop}

Adapun spesifikasi perangkat keras (hardware) laptop yang dibutuhkan sebagai berikut:

Tabel 3.1 Spesifikasi Hardware Laptop

\begin{tabular}{|c|c|c|}
\hline No & Perangkat Keras & Spesifikasi \\
\hline 1 & Laptop & $\begin{array}{ll}\text { - } & \text { Processor Intel Core } \\
& \text { i3-3720M 2,40 GHz } \\
\text { - } & \text { RAM } 4 \text { GB DDR } 3 \\
\text { - } & \text { Intel HD Graphic } \\
& 3000 \\
\text { - } & \text { Harddisk } 500 \mathrm{~GB}\end{array}$ \\
\hline
\end{tabular}


b. Smartphone

Adapun spesifikasi perangkat keras (hardware) smartphone yang dibutuhkan sebagai berikut:

Tabel 3.2 Spesifikasi Hardware Smartphone

\begin{tabular}{|l|c|c|}
\hline No & Perangkat Keras & Spesifikasi \\
\hline & & - Processor Quad- \\
& & Core $1,25 \mathrm{GHz}$ \\
& Smartphone & - RAM $2 \mathrm{~GB}$ \\
& & - ROM $16 \mathrm{~GB}$ \\
\hline
\end{tabular}

2. Perangkat Lunak (Software)

Untuk melakukan penelitian dalam merancang bangun aplikasi dibutuhkan dua perangkat lunak (software) yaitu laptop dan smartphone dengan spesifikasi sebagai berikut:

a. Laptop

Adapun spesifikasi perangkat lunak (software) laptop yang dibutuhkan sebagai berikut:

Tabel 3.3 Spesifikasi Software Laptop

\begin{tabular}{|c|l|l|}
\hline No & \multicolumn{1}{|c|}{ Perangkat Lunak } & \multicolumn{1}{|c|}{ Spesifikasi } \\
\hline 1 & Sistem Operasi & Windows 764bit \\
\hline 2 & Text Editor & Sublime 3 \\
\hline 3 & Basis data & MySQL \\
\hline 4 & Bahasa Pemrograman & JavaScript \\
\hline 5 & Server & XAMPP \\
\hline 6 & $\begin{array}{l}\text { Development } \\
\text { Environment) }\end{array}$ & Android Studio Versi 3.3.2 \\
\hline 7 & $\begin{array}{l}\text { SDK (Software } \\
\text { Development Kit) }\end{array}$ & JDK (Java Development Kit) \\
\hline 8 & $\begin{array}{l}\text { Desain Interface dan } \\
\text { Mockup }\end{array}$ & CorelDraw 2018 \\
\hline
\end{tabular}

b. Smartphone

Adapun spesifikasi perangkat lunak (software) smartphone yang dibutuhkan sebagai berikut:

Tabel 3.4 Spesifikasi Software Smartphone

\begin{tabular}{|c|l|c|}
\hline No & \multicolumn{1}{|c|}{ Perangkat Lunak } & Spesifikasi \\
\hline 1 & Sistem Operasi & Android Lollipop Versi 5.2. \\
\hline
\end{tabular}

\section{Hasil Dan Pembahasan}

\section{Analisa Program}

Analisa program yang sedang berjalan didefinisikan sebagai penguraian dari suatu sistem yang utuh menjadi komponennya dengan maksud untuk mengidentifikasi dan mengevaluasi permasalahan yang terjadi. Adapun proses yang dilakukan dapat dilihat pada flowmap diagram berikut:

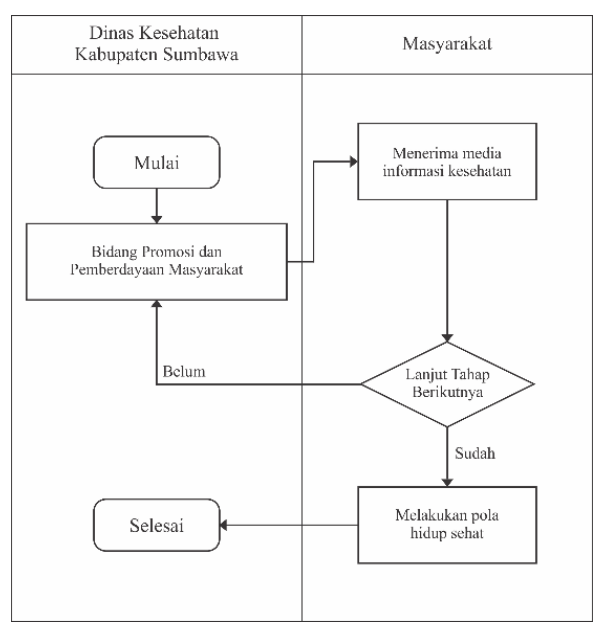

Gambar 3.3 Flowmap Program Sedang Berjalan

\section{Rancangan Sistem Usulan}

Berdasarkan identifikasi masalah yang telah dilakukan, Adapun alur kerja sistem yang diusulkan yaitu:

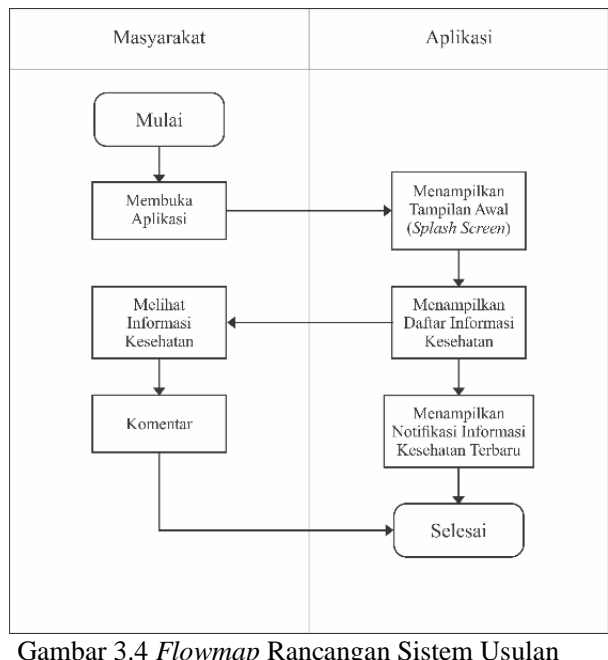

3. Perancangan Aplikasi

a. Use Case Diagram

Pada bagian use case diagram dibagi menjadi dua bagian, yang digambarkan sebagai use case diagram admin dan use case diagram user. Berikut ini adalah use case diagram pada Rancang Bangun Aplikasi Media Promosi Hidup Sehat Berbasis Android:

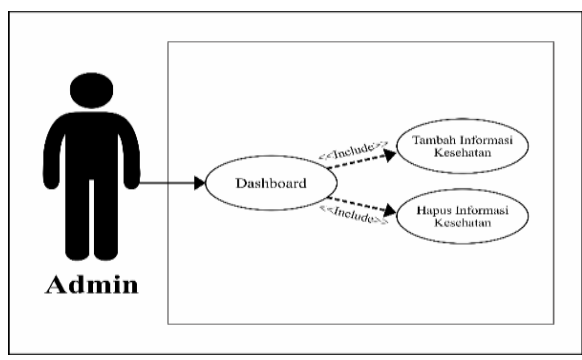

Gambar 3.5 Use Case Diagram User 


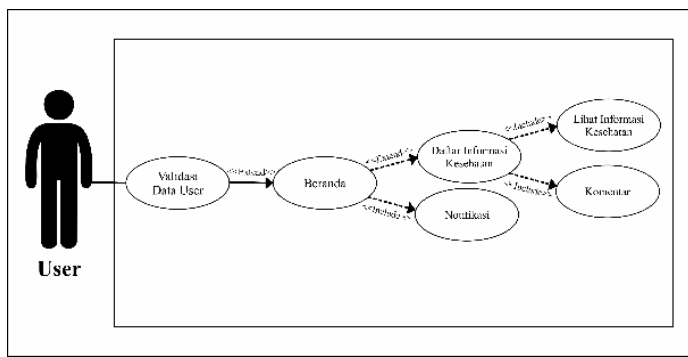

Gambar 3.6 Use Case Diagram User

b. Activity Diagram

Activity diagram adalah representasi grafis dari seluruh tahapan alur kerja yang mengandung aktivitas, pilihan tindakan, perulangan dan hasil dari aktivitas tersebut. Diagram ini dapat digunakan untuk menjelaskan proses bisnis dan alur kerja operasional secara langkah demi langkah dari komponen suatu aplikasi. Dibawah ini adalah activity diagram pada Rancang Bangun Aplikasi Media Promosi Hidup Sehat Berbasis Android sebagai berikut:

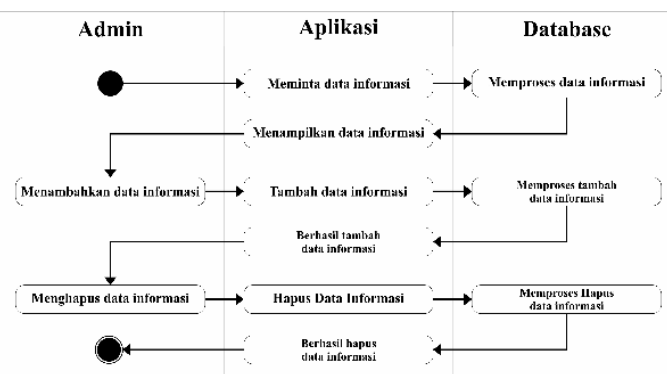

Gambar 3.7 Activity Diagram Dashboard Admin

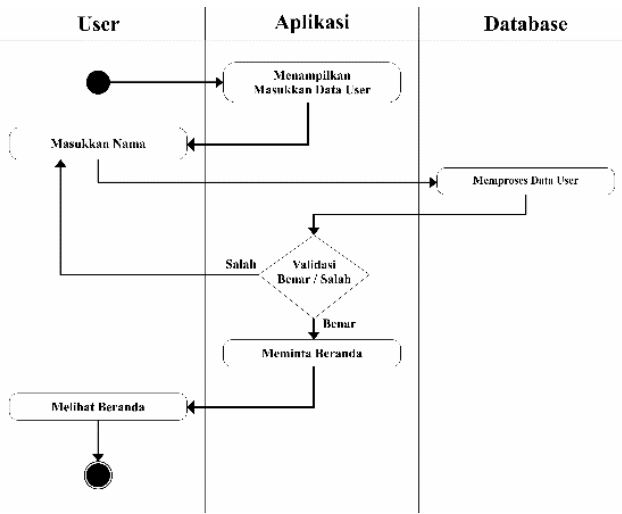

Gambar 3.8 Activity Diagram Validasi Data User

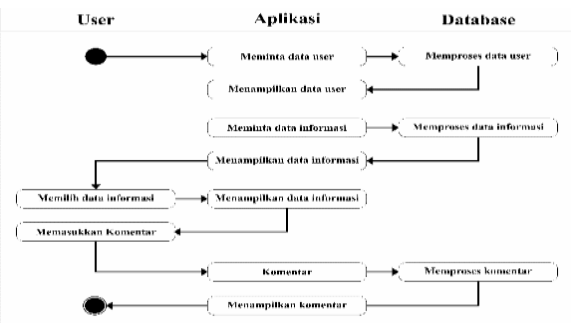

Gambar 3.9 Activity Diagram User

\section{c. Squence Diagram}

Sequence diagram pada aplikasi ini dibagi menjadi dua bagian yaitu bagian admin dan bagian user, setiap bagian mempunyai beberapa sequence diagram yang berfungsi untuk menggambarkan interaksi antar objekobjek yang ada, berikut ini adalah sequence diagram pada Rancang Bangun Aplikasi Media Promosi Hidup Sehat Berbasis Android:

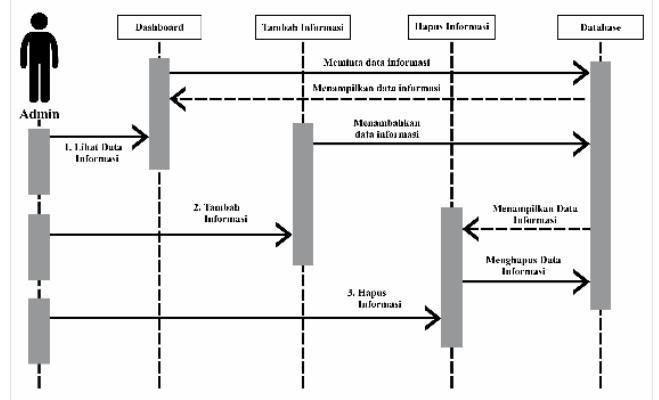

Gambar 3.10 Sequence Diagram Dashboard Admin

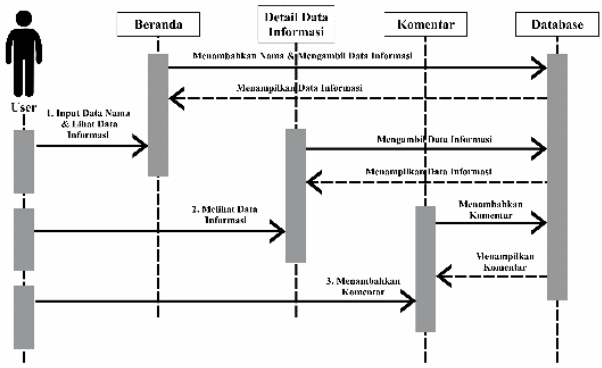

Gambar 3.11 Sequence Diagram User

\section{d. Class Diagram}

Class diagram pada aplikasi ini menunjukkan interaksi antar kelas dan aplikasi serta garis yang dihubungkan antar kelas menunjukkan hubungan komunikasi antara class diagram. Berikut ini merupakan class diagram pada Rancang Bangun Aplikasi Media Promosi Hidup Sehat Berbasis Android:

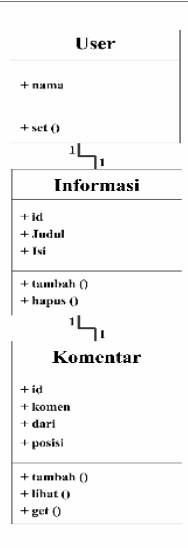

Gambar 3.12 Class Diagram 
4. Perancangan Database Fisik

Database fisik pada aplikasi ini berfungsi untuk menggambarkan tabel yang ada pada database aplikasi, berikut adalah tabel database fisik Rancang Bangun Aplikasi Media Promosi Hidup Sehat Berbasis Android:

a. Tabel Content Sehat

Tabel content sehat dalam hal ini adalah data content sehat yang berfungsi untuk menampung data informasi kesehatan. Tabel content sehat yang terdiri dari id, judul, dan isi dengan struktur sebagai berikut:

Tabel 3.5 Content Sehat

\begin{tabular}{|l|l|c|c|}
\hline Nama Field & Tipe Data & Ukuran Field & Keterangan \\
\hline id & int & 11 & primary key \\
\hline judul & varchar & 200 & \\
\hline isi & text & - & \\
\hline
\end{tabular}

Keterangan:

1. Id merupakan primary key pada tabel content sehat yang digunakan untuk menyimpan data id content sehat.

2. Judul digunakan untuk menyimpan data judul.

3. Isi digunakan untuk menyimpan data isi.

b. Tabel Komenan

Tabel komenan dalam hal ini adalah data komentar yang berfungsi untuk menampung data komentar. Tabel komenan yang terdiri dari $i d$, komen, dari, dan posisi dengan struktur sebagai berikut:

Tabel 3.6 Komenan

\begin{tabular}{|l|l|c|c|}
\hline Nama Field & Tipe Data & Ukuran Field & Keterangan \\
\hline id & int & 11 & primary key \\
\hline komen & text & - & \\
\hline dari & varchar & 200 & \\
\hline posisi & varchar & 200 & \\
\hline
\end{tabular}

Keterangan:

1. Id merupakan primary key pada tabel komenan yang digunakan untuk menyimpan data id komenan.

2. Komen digunakan untuk menyimpan data komentar.

3. Dari digunakan untuk menyimpan data nama pengguna.

4. Posisi digunakan untuk menyimpan data posisi.

5. Implementasi Program

Adapun implementasi program dalam pembuatan Aplikasi Media Promosi Hidup Sehat Berbasis Android adalah sebagai berikut:

a. Antarmuka Dashboard Admin

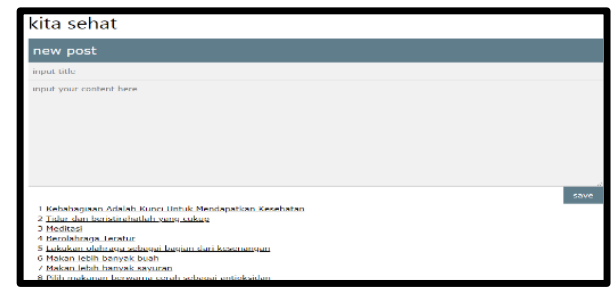

Gambar 3.13 Antarmuka Dashboard Admin

Pada gambar 313 diatas merupakan tampilan dashboard admin yang dimana admin dapat melakukan aktivitas seperti memasukkan dan menghapus informasi kesehatan.

b. Antarmuk

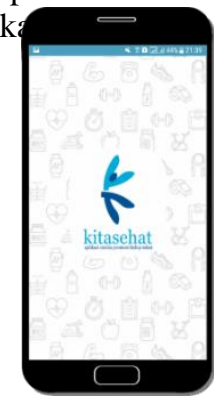

Gambar 3.14 Antarmuka Splash Screen

Pada gambar 3.14 diatas merupakan tampilan pertama program yang muncul sementara ketika user sebelum masuk ke beranda. Terdapat antarmuka splash screen yang didalamnya terdiri dari logo yang dinamakan kitasehat serta terlihat background yang menggambarkan tentang kesehatan.

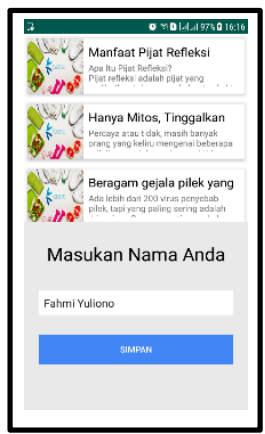

Gambar 3.15 Antarmuka Memasukkan Data User

Pada gambar 3.15 diatas merupakan tampilan program yang dimana user harus memasukkan data terlebih dahulu guna sebagai identitas user yang nantinya ketika user telah memasukkan nama, user dapat memberikan komentar disetiap informasi kesehatan yang telah dilihat oleh user. Setelah memasukkan nama, user dapat melihat beranda informasi kesehatan yang telah diinput oleh admin. 


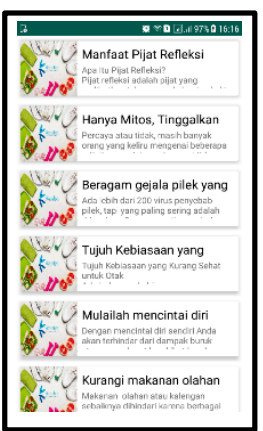

Gambar 3.16 Antarmuka Beranda

Pada gambar 3.16 diatas merupakan tampilan program beranda informasi kesehatan, user dapat melihat daftar informasi kesehatan dan user dapat melihat salah satu informasi kesehatan yang sedang diinginkan tentunya dengan cara yang mudah hanya cukup user tersebut klik informasi yang diinginkan.

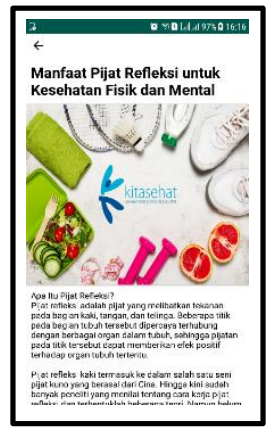

Gambar 3.17 Informasi Kesehatan

Pada gambar 3.17 diatas merupakan tampilan informasi kesehatan, user dapat melihat informasi kesehatan yang telah dipilih. Didalamnya terdapat button kembali ke beranda, lalu dibawahnya terdapat judul informasi kesehatan, lalu ada gambar, kemudian dibawah gambar terdapat informasi kesehatan yang telah dipilih oleh user sebelumnya dan dapat dibaca oleh user.

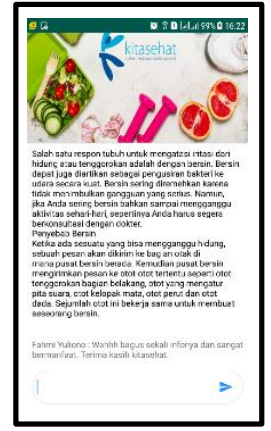

Gambar 3.18 Antarmuka Komentar

Pada gambar 3.18 diatas merupakan tampilan program informasi kesehatan beserta fitur komentar, yang dimana user dapat memberikan komentar terkait informasi kesehatan yang telah dibaca.

\section{Hasil Pengujian}

Pengujian dilakukan dengan menguji setiap proses dan kemungkinan kesalahan yang terjadi untuk setiap proses. Adapun pengujian sistem yang digunakan adalah Blackbox atau yang biasa disebut dengan pengujian struktural melibatkan pengetahuan teknis terperinci. Adapun hasil dari pengujian pada sistem ini adalah sebagai berikut:

a. Pengujian Dashboard Admin Tabel 6 Pengujian Dashboard Admin

\begin{tabular}{|c|c|c|c|}
\hline $\begin{array}{l}\text { Data Masukan } \\
\text { Menambahkan } \\
\text { informasi kesehatan }\end{array}$ & $\begin{array}{l}\text { Yang Diharapkan } \\
\text { Akan tampil notifikasi } \\
\text { kitasehat menyatakan } \\
\text { stuccess }\end{array}$ & \begin{tabular}{l}
\multicolumn{1}{c}{ Pengamatan } \\
$\begin{array}{l}\text { Berhasil menambahkan } \\
\text { informasi kesehatan }\end{array}$
\end{tabular} & $\begin{array}{l}\text { Kesimpulan } \\
\text { [V] Diterima } \\
{[\text { ] Ditolak }}\end{array}$ \\
\hline $\begin{array}{l}\text { Menghapus } \\
\text { inlormasi kesehatan }\end{array}$ & $\begin{array}{l}\text { Akan tampil notifikasi } \\
\text { kitasehat menyatakan } \\
\text { success }\end{array}$ & $\begin{array}{l}\text { Berhasil menghapus } \\
\text { informasi kesehatan }\end{array}$ & $\begin{array}{l}{[\sqrt{ }] \text { Diterima }} \\
\text { [ ] Ditolak }\end{array}$ \\
\hline
\end{tabular}

b. Pengujian Notifikasi

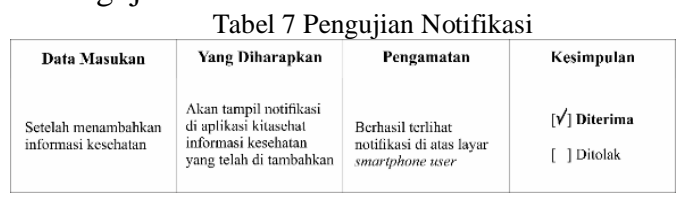

c. Pengujian Masukkan Data User Tabel 8 Pengujian Masukkan Data User

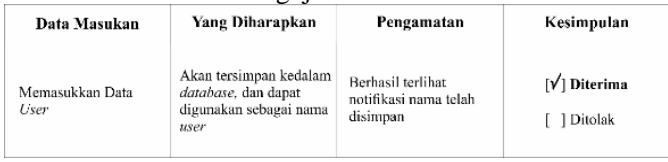

d. Pengujian Beranda

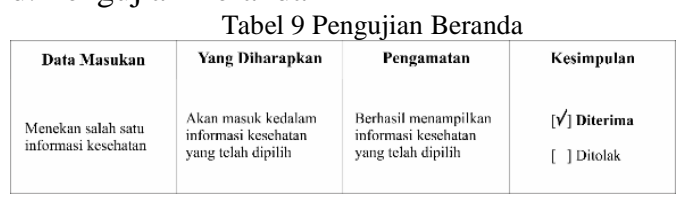

e. Pengujian Komentar

\begin{tabular}{|c|c|c|c|}
\hline \multicolumn{4}{|c|}{ Tabel 10 Pengujian Komentar } \\
\hline Data Masukan & Yang Diharapkan & Pengamatan & Kesimpulan \\
\hline $\begin{array}{l}\text { Memasukkan } \\
\text { komentar }\end{array}$ & $\begin{array}{l}\text { Akan menampilkan } \\
\text { komentarar di bavahah isi } \\
\text { informasi kesehatan }\end{array}$ & $\begin{array}{l}\text { Berhasil berhasil } \\
\text { menambahkhan } \\
\text { \& Menampillkan } \\
\text { komentar }\end{array}$ & $\begin{array}{l}{[\sqrt{ } \mid \text { Diterima }} \\
{[\text { ] Ditolak }}\end{array}$ \\
\hline
\end{tabular}

\section{Kesimpulan Dan Saran}

\section{Kesimpulan}

Aplikasi Media Promosi Hidup Sehat Berbasis Android sudah selesai dirancang dengan perancangan berorientasi objek dan dibangun menggunakan bahasan pemrograman Java di Android Studi versi 3.3.2. Aplikasi telah menyajikan data informasi kesehatan yang dapat menjadi masukan kepada Dinas Kesehatan Kabupaten Sumbawa guna mengembangkan proses penyajian data informasi bagi masyarakat terkait segala hal yang bertujuan pada peningkatan kualitas kesehatan, baik itu kesehatan individu maupun masyarakat serta memberikan kemudahan bagi pengguna untuk mengelola hidup sehat yang tepat.

\section{Saran}

Aplikasi Media Promosi Hidup Sehat Berbasis Android ini sudah tentu masih jauh dari kata sempurna dan masih memiliki banyak kekurangan. 
Untuk itu perlu dilakukan pengembangan dan penyempurnaan aplikasi agar lebih baik. Adapun saran yang dapat disampaikan mengenai Aplikasi Media Promosi Hidup Sehat Berbasis Android ini adalah sebagai berikut:

a. Fitur dari aplikasi dapat ditambahkan, seperti informasi yang disajikan, kurangnya penggunaan animasi dan buttonbutton pembantu lainnya. Diharapkan kedepannya untuk ditambahkan fitur-fitur tersebut agar aplikasi semakin nyaman digunakan.

b. Aplikasi secara regulasi/kebijakan diterapkan oleh Dinas Kesehatan Kabupaten Sumbawa dengan implementasi pada hosting dan upload ke playstore agar memudahkan admin serta user mendapatkan jangkauan yang lebih luas dalam mengoperasikan aplikasi tersebut.

Demikian saran yang dapat penulis berikan, semoga saran tersebut dapat dijadikan sebagai bahan masukan yang bermanfaat bagi penulis khususnya dan pengembangan pada umumnya.

\section{DAFTAR PUSTAKA}

Amin, Muhammad. 2016. “Analisis Penjualan Komputer Pada Putra Jawa Komputer Berbasis Web". Jurnal Tecnologia. Vol 7 No.4 Hal. 253. Tanggal Akses: 2 Maret 2019.

Berita Satu. 2013. Survei Kesehatan AIA: Pola Hidup Masyarakat Indonesia Terburuk di Asia Pasifik. https://www.beritasatu.com/asuransi/1564. 19 Desember 2013.

Creswell, John W. 2009 "Research design: Qualitative, quantitative, and mixed methods approaches 3rd Ed". United States of America, SAGE Publications, Inc.

Gitosudarmo, Indiryo. 2014. Manajemen Pemasaran. Cetakan ketiga, Edisi kedua. Yogyakarta: BPEE.

Lupiyoadi, Rambat, dan A. Hamdanu.2006. Manajemen Pemasaran Jasa. Edisi Kedua. Jakarta: Salemba Empat.

Pressman, Roger S. 2005. Software engineering: a practitioner's approach. New York: McGrawHill Higher Education.

Profil Kesehatan Kabupaten Sumbawa Tahun 2016. 2017. Sumbawa: Dinas Kesehatan.

Safaat, H. Nazruddin. 2012 (Edisi Revisi). Pemograman Aplikasi Mobile Smartphone dan Tablet PC Berbasis Android. Informatika. Bandung.

Sujadi, Harun. 2015. "Sistem Pakar Penyakit Dengan Gejala Demam.

Menggunakan Perangkat Mobile Berbasis Android". Jurnal J-Ensitec. Vol.

1 No. 12 Hlm. 41.
Pembelajaran Inovatif. Yogyakarta: Graha Ilmu.

Sukarsih, Karti Hari. 2002. Media Pembelajaran dan Jenis-jenis Media Pembelajaran. Jakarta: PT Raja Grafindo Persada.

Supardi, Ir. Yuniar. 2017. Koleksi Program Tugas Akhir dan Skripsi dengan Android. Jakarta: Elex Media Komputindo.

Suyito, Sandu. (2015). "Dasar Metodologi Penelitian. Yogyakarta, Literasi Media Publishing Drew, Jesse. (2013). A Social History of Contemporary Democratic Media. Routledge: London.

Sutirman, 2013. Media \& Model-model 